\title{
Segmental neurofibromatosis is caused by somatic mutation of the neurofibromatosis type 1 (NF1) gene
}

\author{
Sigrid Tinschert ${ }^{1}$, Ilka Naumann ${ }^{1}$, Elisabeth Stegmann ${ }^{2}$, Annegret Buske $^{1}$, \\ Dieter Kaufmann ${ }^{3}$, Gundula Thiel ${ }^{1}$ and Dieter E Jenne ${ }^{2}$ \\ ${ }^{1}$ Institut für M edizinische Genetik, Universitätsklinikum Charité, Humboldt-Universität zu Berlin; ${ }^{2}$ Abteilung \\ Neuroimmunologie, Max-Planck-Institut für N eurobiologie, Planegg Martinsried; ${ }^{3}$ Abteilung Humangenetik, \\ Universität UIm, Germany
}

\begin{abstract}
Segmental neurofibromatosis (NF) is generally thought to result from a postzygotic NF1 (neurofibromatosis type 1) gene mutation. However, this has not yet been demonstrated at the molecular level. Using fluorescence in situ hybridisation (FISH) we identified an NF1 microdeletion in a patient with segmental NF in whom café-au-lait spots and freckles are limited to a single body region. The mutant allele was present in a mosaic pattern in cultured fibroblasts from a café-au-lait spot lesion, but was absent in fibroblasts from normal skin as well as in peripheral blood leukocytes. These findings prove the hypothesis that the molecular basis of segmental cutaneous NF is a mutation in the NF1 gene and that the regional distribution of manifestations reflects different cell clones, commensurate with the concept of somatic mosaicism. European Journal of Human Genetics (2000) 8, 455-459.
\end{abstract}

Keywords: Segmental neurofibromatosis; FISH; NF1 gene deletion; microdeletion; somatic mosaicism

\section{Introduction}

Despite the number of articles dealing with localised cutaneous or segmental NF since its first description in 1931 by Gammel, ${ }^{1}$ obscurity and controversy still surround this topic. The aetiological concept of somatic mutation, generally accepted today, was al ready suggested in $1956 .{ }^{2}$ However, the definition given by Riccardi, ${ }^{3,4}$ who required strict onesidedness of NF1 features such as café-au-lait spots, freckling and/or neurofibromas without crossing the midline was too restrictive when viewed in the light of current knowledge of mosaicism. The strictly defined segmental NF was termed NF5 in Riccardi's clinical classification of the neurofibromatoses into eight groups. ${ }^{4}$ Broader definitions were given by Roth $^{5}$ and Combemale et al. ${ }^{6}$ Their classification schemes, however, which include heritable and non-heritable clinically distinguishable subtypes were not in agreement with genetic knowledge. A classification for neurofibromatoses into NF1, NF2, alternate and related forms of either NF1 or NF2 was proposed by Viskochil and Carey, ${ }^{7}$ according to the present understanding of the molecular aspects of neurofi-

Correspondence: Dr Sigrid Tinschert, Universitätsklinikum (Charité), Institut für Medizinische Genetik, D-10098 Berlin, Germany. Tel: +4903 2802 3731; Fax: +4903 2802 1136; E-mail:

sigrid.tinschert@charite.de

Received 9 December 1999; revised 29 February 2000; accepted

7 March 2000 bromatoses. Segmental NF, defined by regionally limited cutaneous signs of NF1, is placed in the category of alternate forms comprising those conditions with some of the respective clinical features of NF1 or NF2.

The concept of mosaicism explains the various clinical presentations of segmental NF. The phenotype may be predicted by the timing of the NF1 mutation, the type of the mutation, the particular lineage and the viability of the cells bearing the mutation, as well as by the body region involved. Furthermore, somatic mosaicism explains the few reports on segmental NF in parents of children with generalized NF1. ${ }^{8-12}$ It is assumed that in these parents the postzygotic mutation occurred early in a pluripotent precursor cell $\mathrm{I}^{13}$ and results in both somatic cell and gonadal cell mosaics. ${ }^{14}$ However, the molecular basis of these cases was not elucidated.

In the present report we offer the first molecular demonstration of NF1 gene mosaicism as the cause of segmental NF.

\section{Subject, material and methods} Subject

The 18-year-old male has a clearly demarcated area of freckling scattered predominantly on the left side of the neck, upper trunk, axilla and arm associated with café-au-lait spots (two larger than $15 \mathrm{~mm}$ and seven of 5 up to $15 \mathrm{~mm}$ in 
diameter) limited to this area (Figure1). The demarcation of freckling follows the lines of Blaschko with an arc shape on the chest and a fountain-like, V-shaped pattern over the midline on the back. Reportedly, the freckled lesion was present at birth. There are no neurofibromas or Lisch
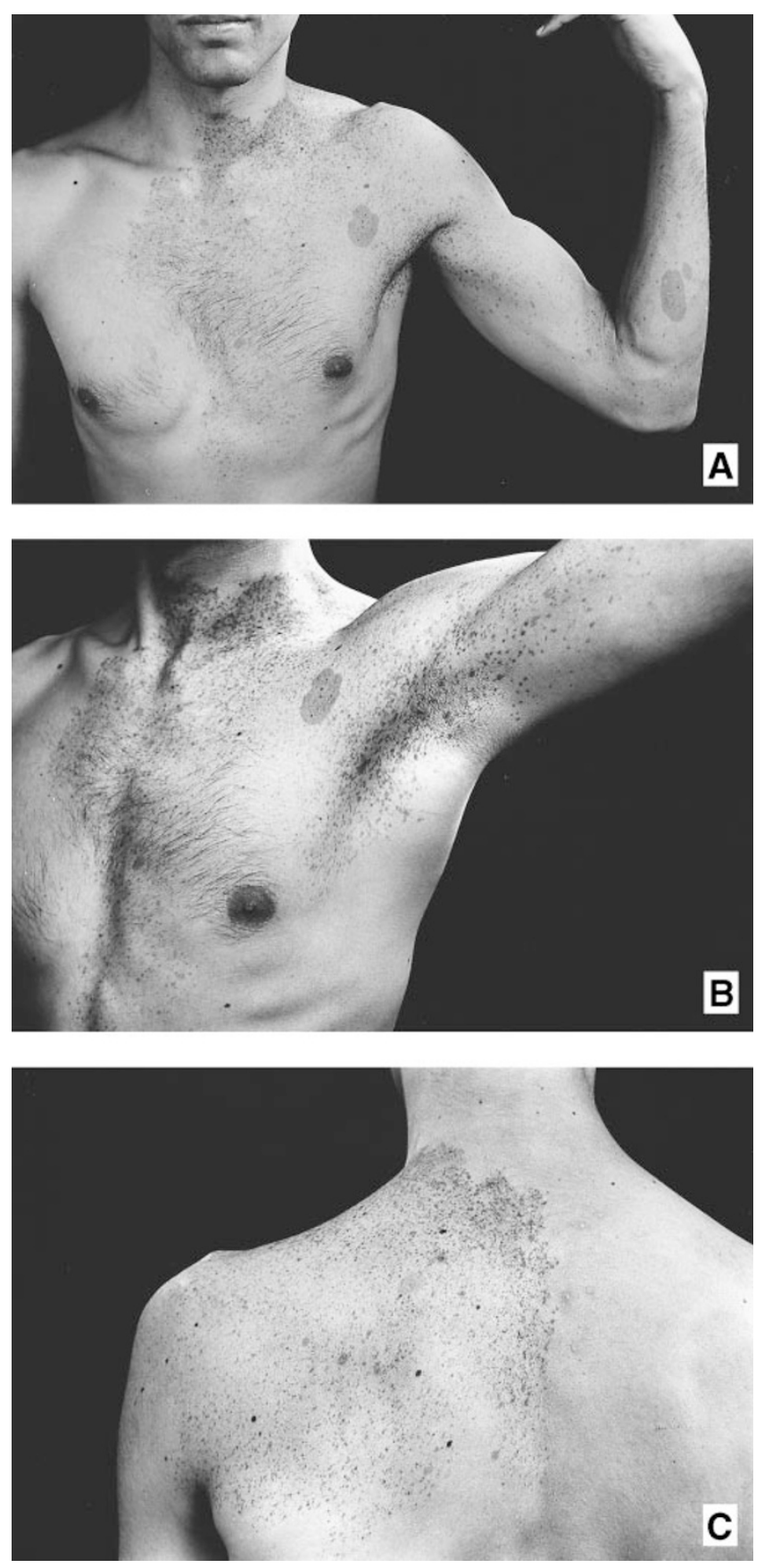

Figure 1 Distribution of freckling on upper chest and left arm with typical café-au-lait spots present in this area. Biopsy was taken from the large café-au-lait spot on the forearm (A). Axillary freckling (B). Distribution of freckling and café-au-lait spots on upper back (C). nodules. The thorax is asymmetric, and the involved left side was slightly smaller on radiograph. No scoliosis or other chest malformation is present. The family history is unremarkable. The mother of the patient is German and the father Lebanese.

\section{Samples}

Superficial 3-mm punch biopsies were taken from the skin of a café-au-lait spot lesion measuring $40 \mathrm{~mm}$ in diameter on the left forearm (Figure1A) and from a non-affected area on the right upper arm. From each sample fibroblasts were cultured using standard methods. Hair samples were taken from affected and unaffected regions and hair follicle cells were extracted by standard procedures. A heparinised venous blood sample was obtained.

\section{Cosmid and BAC probes}

Cosmid clones were identified by filter hybridisation of a chromosome17 specific cosmid library ICRFc105 using two different probes from the NF1 gene. The $5^{\prime}$ probe was amplified with the forward and reverse primers 5'-AGATAACTCTGTCATITTCCTAC-3' and 5'-CTATCCATAGAGGAGTTCGCT-3' and covered exons 7 to 12; this probe hybridised to eight different cosmids including A04138. A 3 ' CDNA probe of NF1 which extended from exon 36 to exon 46 was generated by PCR using the primers 5'-CCAGTGGACAGAACTAGCTC-3' and 5'-GGCCTCTGCTAAGTATTCATA-3'. In total eight cosmids including G02121 were identified with this probe. Cosmid ends were sequenced with the help of T7 and SP6 primers that flank the Bam $\mathrm{HI}$ cloning site. Cosmid A04138 covers the $5^{\prime}$ portion of the NF1 gene from exon $4 \mathrm{~b}$ up to exon 9a, cosmid G02121 covers the $3^{\prime}$ end of the gene and extends from exon 29 until exon 48. Numbering of exons is according to $\mathrm{Li}$ et al. ${ }^{15}$

To examine the extent of the deletion in fibroblasts from our patient, we used well characterised and physically mapped BAC clones that flank the breakpoints in the majority of NF1 patients with constitutional microdeletions around the NF1 locus. The partially overlapping BACS R-271K11 and 2309P3 flank the proximal breakpoint region, whereas the contiguous BACs 307A16 and R-640N20 surround the distal breakpoints in five out of seven patients with microdeletions. ${ }^{16}$

\section{Molecular cytogenetic investigations}

Metaphases were prepared from fibroblasts of the café-au-lait spot lesion, and of the unaffected skin as well as from peripheral blood lymphocytes of the proband. Metaphases from dermal fibroblasts and lymphocytes of two control persons were also prepared. FISH was performed on metaphases by applying intragenic cosmids c105A04138 and c105G02121 (see below). For chromosome identification and to exclude loss of chromosome17 the p53 probe (Vysis, Downers Grove, IL, USA) localised at $17 \mathrm{p} 13.1$ was used. A minimum of 20 metaphases was examined (average 45). The 
studies were done on two separate preparations of metaphases (Table1, I and II) from a culture re-established from frozen fibroblasts after the second passage of the primary fibroblast culture from the café-au-lait spot. Metaphases from dermal fibroblasts and lymphocytes of two control persons (Table1) were also prepared.

To study the extent of tissue involvement, we examined interphase nuclei extracted from hair follicle cells obtained from hairs of affected and unaffected body regions of the patient. FISH was performed using the BACs described above.

\section{Results}

Conventional karyotyping showed a normal 46,XY karyotype using GTG banding in all samples. The signals for the two intragenic NF1 gene cosmids c105A04138 and c105G02121 were detected on both copies of chromosome17 in all metaphases from peripheral lymphocytes and from cultured fibroblasts of unaffected skin of the proband. Two signals were also obtained in $98-100 \%$ of metaphases from peripheral lymphocytes $(n=50)$ and $100 \%$ of metaphases from dermal fibroblasts $(n=20)$ of two control persons. In the fibroblasts from the café-au-lait spot lesion, hybridisation signals were observed from only one chromosome17 suggesting deletion in $16.5 \%$ (range 16-17) of metaphases. This result was reproducible (19.5\%, range $15-24)$ in a second experiment using metaphases from cultured fibroblasts reestablished from the same passage (Table1). Since the cosmids span nearly the entire NF1 gene, lack of the signals for both cosmids indicates a microdeletion larger than the NF1 gene. Therefore we mapped the extent of the deleted region using several BACs including $\mathrm{R}-271 \mathrm{~K} 11,230 \mathrm{P3}$, $307 A 16$ and R-640N20. The same BAC probes were previously found to delimit the deleted segment in the majority of NF1 patients with microdeletions. ${ }^{16}$ Similar findings on the breakpoint locations in NF1 microdeletions were recently published by Dorschner et al. ${ }^{17}$ In all fibroblasts from the patient we observed two signals with the BACs R-271K11 and R-640N20, but we obtained only one signal with the BACs $2309 \mathrm{P} 3$ and $307 \mathrm{~A} 16$ in about 15\% of fibroblasts derived from skin biopsies of the affected body region similar to the results with intragenic probes. These findings clearly establish the clonal origin of segmental NF1 manifestations in our patient and excludes the loss of variable portions of the long arm of chromosome17 in affected fibroblasts.

Interphase nuclei of epithel cells associated with hair follicles did not show deletions of the NF1 locus. Thus our data imply that the microdeletion around the NF1 locus occurred in a precursor cell that was already committed to the fibroblast lineage.

\section{Discussion}

The regionally restricted distribution of skin lesions in segmental NF and the lack of antecedent family history of the affected persons whose offspring can show full-blown NF1 have suggested that segmental NF results from a postzygotic NF1 gene mutation. To date, this hypothesis had not been proven at the molecular level.

The failure of our attempts (data not shown) to identify the molecular defect in the person with segmental NF by protein truncation test (PTT) and temperature gradient gel electrophoresis (TGGE) ${ }^{18}$ prompted us to perform FISH analyses.

By FISH studies we identified an NF1 gene deletion spanning the entire gene in some (on average 18\%) of the fibroblasts cultured from a café-au-lait spot. The mutation was absent in peripheral leukocytes as well as cultured dermal fibroblasts from a non-affected body region. These findings confirm the previous suggestions that (i) segmental NF is

Table 1 Results of fluorescence in situ hybridisation (FISH) analyses in segmental NF using intragenic cosmid probes

\begin{tabular}{|c|c|c|c|}
\hline Cosmid probe, site & Number of metaphases & One signal & $\%$ of cells with deletion \\
\hline $\begin{array}{l}\text { c105 A04138 } \\
\text { fibroblasts from café-au-lait spot (I) } \\
\text { fibroblasts from café-au-lait spot (II) } \\
\text { fibroblasts from unaffected skin (proband) } \\
\text { fibroblasts from unaffected skin (control 1) } \\
\text { fibroblasts from unaffected skin (control 2) } \\
\text { peripheral blood lymphocytes (proband) } \\
\text { peripheral blood lymphocytes (control 1) } \\
\text { peripheral blood lymphocytes (control 2) }\end{array}$ & $\begin{array}{l}54 \\
62 \\
48 \\
20 \\
20 \\
61 \\
51 \\
50\end{array}$ & $\begin{array}{r}9 \\
15 \\
0 \\
0 \\
0 \\
1 \\
1 \\
0\end{array}$ & $\begin{array}{r}17 \\
24 \\
0 \\
0 \\
0 \\
2 \\
2 \\
0\end{array}$ \\
\hline $\begin{array}{l}\text { c105 G02121 } \\
\text { fibroblasts from café-au-lait spot (I) } \\
\text { fibroblasts from café-au-lait spot (II) } \\
\text { fibroblasts from unaffected skin (proband) } \\
\text { fibroblasts from unaffected skin (control 1) } \\
\text { fibroblasts from unaffected skin (control 2) } \\
\text { peripheral blood lymphocytes (proband) } \\
\text { peripheral blood lymphocytes (control 1) } \\
\text { peripheral blood lymphocytes (control 2) }\end{array}$ & $\begin{array}{l}44 \\
53 \\
25 \\
20 \\
20 \\
50 \\
50 \\
50\end{array}$ & $\begin{array}{l}7 \\
8 \\
0 \\
0 \\
0 \\
0 \\
0 \\
0\end{array}$ & $\begin{array}{r}16 \\
15 \\
0 \\
0 \\
0 \\
0 \\
0 \\
0\end{array}$ \\
\hline
\end{tabular}


indeed due to an NF1 gene mutation and (ii) that affected individuals are mosaics.

The presence of different fibroblast cell lines is not unexpected, even in a single affected area and unambiguously indicates somatic mosaicism. Cytogenetic studies on patients with chromosomal mosaicism and pigmentation disturbances showed almost al ways a mixture of normal and aberrant fibroblast cell lines in biopsies taken from affected skin. ${ }^{19-21}$ In the McCune-Albright syndrome, for example, a monogenic mosaic condition, the underlying mutation in the GNAS1 gene was detected at very low levels in genomic DNA isolated from a localised pigmented skin lesion. ${ }^{22}$ We recently showed the presence of the mutant GNSA1 allele in a range from 2 to $45 \%{ }^{23}$ in uncultured dysplastic bone specimens of a patient with the McCune-Albright syndrome. The mutant GNAS1 allele was detected in a range of $0-84 \%$ after cell culturing even when starting from the same material. These data demonstrate how cell culturing can introduce a strong bias into the results obtained from mosaic tissue. Both, low-level mosaicism and unfavourable cell culturing may account for unsuccessful mutation detection in segmental NF.

Four NF1 patients from the literature have been shown to be mosaics on a molecular level, ${ }^{24-27}$ but the cutaneous features of NF1 have been described as generalised and not restricted to a given region. In these patients, the mutant alleles (all mutations have been gross deletions) were present in the majority of the peripheral blood lymphocytes, but could not be detected in dermal fibroblasts of three patients investigated. ${ }^{24,26,27}$ However, mosaicism was found in two dermal neurofibromas in the patient described by Colman. ${ }^{24}$ It remains unclear whether there was really no mosaicism in the skin of these patients or if mutated alleles were not detectable. In contrast to these findings, the person with segmental NF reported here presented with an NF1 deletion in dermal fibroblasts of a pigmented NF1 lesion but not in blood leukocytes. Further studies are needed to clarify the tissue distribution of mosaicism in segmental NF.

It may be speculated that the mild hypoplasia of the proband'sleft trunk, the side affected by the NF1 lesions, may be related to the effect of the (regional) NF1 gene mutation since body height is often reduced in NF1. However, we do not know the extent of tissue involvement in the present case. Skel etal signs of hypoplastic asymmetry are not uncommon in chromosomal mosaicism involving a single chromosome of a different kind or a whole set of chromosomes. Furthermore, asymmetric skeletal hypoplasia is a well known feature, eg in the Schimmelpenning syndrome or the Becker nevus syndrome, both proposed to be due to a postzygotic mutation. 28,29

The pigmented lesions in segmental NF have been ascribed to dermatomal segments of the skin that are defined by sensory innervation. In the young man presented here, however, the areas of pigmentation followed the pattern of Blaschko lines. According to a hypothesis proposed by
Happle $e^{30,31}$ the pigmented skin lesions following the lines of Blaschko visualise the dorso-ventral outgrowth of two different populations of cells during embryogenesis and therefore reflect mosaicism. Remarkably, we found two previous reports on a Blaschko line pattern in connection with segmental NF. ${ }^{12,32}$ Further instances have been documented on clinical photographs published in other reports. ${ }^{33,34,35}$ In our opinion there is no reason to assume that pigmented lesions in segmental NF are segmental in a strictly dermatomal sense.

In conclusion, our findings offer direct proof of the previous contention that the occurrence of NF1 features in a restricted area of the body termed segmental NF reflects an underlying somatic mosaicism and may results from a mutation of the NF1 gene. More patients with segmental NF will be needed to elucidate further the mutation spectrum and the tissue distribution of mosaicism in this phenotype.

\section{Acknowledgements}

The authors thank the proband. Thanks are also due to Ingrid Beilfuß, Heike Reimann, and Karin Lehmann for technical assistance. This work was supported in part by the Deutsche Krebshilfe (Contract grant number: 70-2452-Kr3) and by the Sonderforschungsbereich 469 (DE J, project A5) of the German Research Council.

\section{References}

1 Gammel JA: Localized neurofibromatosis. Arch Dermatol 1931; 24: 712-715.

2 Crowe FW, Schull WJ, Neel JV: A Clinical, Pathological, and Genetic Study of Multiple Neurofibromatosis. Charles C Thomas: Springfield, IL, 1956, pp 1-181.

3 Riccardi VM: Neurofibromatosis: clinical heterogeneity. Curr Probl Cancer 1982; 7: 1-34.

4 Riccardi VM: Non-von Recklinghausen NF. In: Riccardi VM (ed). Neurofibromatosis: Phenotype, Natural History, and Pathogenesis. Johns Hopkins University Press: Baltimore, 1992, pp 224-250.

5 Roth RR, Martines R, James WD: Segmental neurofibromatosis. Arch Dermatol 1987; 123: 917-992.

6 Combemale P, Abitan R, Kanitakis J: Segmental neurofibromatosis. Report of two cases and critical review of the literature. Eur J Dermatol 1994; 4: 194-201.

7 Viskochil DH, Carey JC: Alternate and related forms of the neurofibromatoses. In: Huson SM, Hughes RAC (eds). The N eurofibromatoses - A Pathogenetic and Clinical Overview. Chapman \& Hall: London, pp 445-474.

8 Rubinstein $\mathrm{AE}$, Bader JL, Aron AA, Wallace S: Familial transmission of segmental neurofibromatosis. Neurology 1983; 33 (suppl 2): 76 (Abstr).

9 Riccardi VM, Lewis RA: Penetrance of von Recklinghausen neurofibromatosis: a distinction between predecessors and descendants. Am J Hum Genet 1988; 42: 284-289.

10 Boltshauser E, Stocker H, Machler M: Neurofibromatosis type 1 in a child of a parent with segmental neurofibromatosis (NF-5). Neurofibromatosis 1989; 2: 244-245.

11 Theiler R, Stocker H, Boltshauser E: The classification of atypical forms of neurofibromatosis. Schweiz Med Wochenschr 1991; 121: 446-455.

12 Moss C, Green SH: What is segmental neurofibromatosis? $\mathrm{Br}$ J Dermatol 1994; 130: 106-110.

13 Gardner RL: Clonal analysis of early mammalian development. Phil Trans Roy Soc Lond 1985; 312: 163-178. 
14 Huson SM: Neurofibromatosis 1: a clinical and genetic overview. In: Huson SM, Hughes RAC (eds). The Neurofibromatoses - A Pathogenetic and Clinical Overview. Chapman \& Hall: London, 1994, pp 160-203.

$15 \mathrm{Li} \mathrm{Y,} \mathrm{O'Connell} \mathrm{P,} \mathrm{Huntsman-Breidenbach} \mathrm{H}$, Cawthon $\mathrm{R}$ et al: Genomic organization of the neurofibromatosis1 gene (NF1). Genomics 1995; 25: 9-18.

16 Jenne DE, Tinschert S, Stegemann E et al: A common set of at least 11 functional genes are lost in the majority of NF1 patients with gross deletions. Genomics 2000; (in press).

17 Dorschner MO, Sybert VP, Weaver M, Pletcher BA, Stephens K: NF1 microdel etion breakpoints are clustered at flanking repetitive sequences. Hum Mol Genet 2000; 35-46.

18 Fahsold R, Hoffmeyer S, Mischung $\mathrm{C}$ et al: Minor lesion mutational spectrum of the entire NF1 gene does not explain its high mutability but points to a functional domain upstream of the GRD. Am J Hum Genet 2000; 66: 790-818.

19 Thomas IT, Frias JL, Cantu ES, Lafer ChZ, Flannery DB, Graham JG: Association of pigmentary anomalies with chromosomal and genetic mosaicism and chimarism. Am J Hum Genet 1989; 45: 193-205.

20 Ohashi H, Tsukahara M, Murano I et al: Pigmentary dysplasias and chromosomal mosaicism: report of 9 cases. Am J Med Genet 1992; 43: $716-721$.

21 Moss C, Larkins S, Stacey M, Blight A, Farndon PA, Davison EV: Epidermal mosaicism and Blaschko's lines [see comments]. J Med Genet 1993; 30: 752-755.

22 Schwindinger WF, Francomano CA, Levine MA: Identification of a mutation in the gene encoding the alpha subunit of the stimulatory $\mathrm{G}$ protein of adenylyl cyclase in McCune-Albright syndrome. Proc Natl Acad Sci USA 1992; 89: 5152-5156.

23 Tinschert S, Gerl H, Gewies A, Jung HP, Nürnberg P: McCuneAlbright syndrome: clinical and molecular evidence of mosaicism in an unusual giant patient. Am J Med Genet 1999; 83: 100-108.
24 Colman SD, Rasmussen SA, Ho VT, Abernathy CR, Wallace MR: Somatic mosaicism in a patient with neurofibromatosis type 1. Am J Hum Genet 1996; 58: 484-490.

25 Ainsworth PJ, Chakraborty PK, Weksberg R: Example of somatic mosaicism in a series of de novo neurofibromatosis type 1 cases due to a maternally derived deletion. Hum Mutat 1997; 199: 452-457.

26 Tonsgard JH, Yelavarthi KK, Cushner S, Short MP, Lindgren V: Do NF1 gene deletions result in a characteristic phenotype? Am J Med Genet 1997; 73: 80-86.

27 Wu BL, Boles RG, Yaari H, Weremowicz S, Schneider GH, Korf BR: Somatic mosaicism for deletion of the entire NF1 gene identified by FISH. Hum Genet 1997; 99: 209-213.

28 Happle R: Epidermal nevus syndromes. Sem Dermatol 1995; 14 111-121.

29 Happle R: Becker nevus syndrome. Am J Med Genet 1997; 68 357-336.

30 Happle R: Genetische Bedeutung der Blaschko-Linien. Z Hautkr 1977; 52: 935-911.

31 Happle R: Lyonization and the lines of Blaschko. Hum Genet 1985; 70: $200-206$.

32 Winter T, Gall H, Krone W, Sterry W: Neurofibroma with contralateral linear hyperpigmentation along Blaschko lines. Hautarzt 1997; 48: 51-54.

33 Gerhards G, Hamm H: Unilateral Ientiginosis-a segmental neurofibromatosis without neurofibromas. Hautarzt 1992; 43 491-495.

34 Hughes GD, Park HK, Jones BE: Partial unilateral Ientiginosis in a black patient with sickle cell anemia [letter]. J Am Acad Dermatol 1983; 8: 563-565.

35 Lee WS, Yoo MS, Ahn SK, Won JH: Partial unilateral lentiginosis associated with segmental neurofibromatosis. J Dermatol 1995; 22 958-969. 